\title{
COMPLEMENTARIDADE ENTRE UMA ÉTICA DAS VIRTUDES E DOS PRINCÍPIOS NA TEORIA DA JUSTIÇA DE ARISTÓTELES ${ }^{1}$
}

\author{
Denis Coitinho Silveira
}

RESUMO - O objetivo deste artigo é analisar a teoria da justiça de Aristóteles elaborada na Ethica Nicomachea, Livro V, a partir de um certo deslocamento em relação à teoria das virtudes, que faz uso da escolha deliberada do agente, para utilizar-se de critérios mais objetivos baseados na igualdade, em que se encontram aspectos universalistas e procedimentais na constituição dos princípios de justiça na esfera pública, visando identificar uma complementaridade entre uma ética das virtudes e uma ética dos princípios na filosofia prática aristotélica.

PALAVRAS-CHAVE - Aristóteles. Ética das virtudes. Ética dos princípios. Teoria da justiça.
ABSTRACT - The aim of his article is to raise some considerations about Aristotle's theory of justice elaborated in Nicomachean Ethics, Book $\mathrm{V}$, from a certain displacement in relation to the theory of virtues, that makes use of the deliberate choice of the agent, to use itself of based more objective criteria in the equality, where if they find universal and procedural aspects in the establishment of the principles of justice in the public sphere, aiming at to identify a complement between ethics of virtues and ethics of principles in Aristotle's practical philosophy.

KEY WORDS - Aristotle. Ethics of virtues. Ethics of principles. Theory of justice.

\section{Introdução}

Uma das características da retomada da teoria das virtudes contemporaneamente é o eliminacionismo, isto é, o abandono da ética baseada em princípios, como a ética kantiana ou a utilitarista que usam um princípio (universalizabilidade e não-instrumentalização ou utilidade como maximização do bem-estar, respectivamente) para fundamentar o comportamento moral (juízo moral), propondo um critério de correção a partir das virtudes morais da comunidade, que compartilham uma certa tradição moral, ou seja, que estabelece quais comportamentos (ações e emoções) são apreciáveis e quais são censuráveis. Nesta abordagem, parecem poder prescindir de toda referência aos princípios e de toda reflexão sobre os direi-

Este trabalho foi apresentado parcialmente no XII Encontro Nacional de Filosofia da ANPOF/Salvador/2006 no GT-Aristóteles. Agradeço à CAPES/CEBRAP a oferta de condições para o desenvolvimento da pesquisa de pós-doutoramento. Em especial, agradeço ao Prof. Marco Zingano (USP) a tutoria no trabalho e todo apoio oferecido. Ao meu colega, João Hobuss, muito obrigado pela franca discussão e sugestões apresentadas.

Universidade Federal de Pelotas.

\begin{tabular}{|l|l|l|l|l|l|}
\hline VERITAS & Porto Alegre & v. 52 & n. 2 & Junho 2007 & p. 35-55 \\
\hline
\end{tabular}


tos que se desenvolveu a partir da modernidade. Os princípios de liberdade, igualdade, autonomia, diferença são substituídos por critérios de perfeição comportamental como o que é nobre, o que é bom, honorável, apropriado, justo etc. Demonstra requerer uma retomada de um ideal perfeccionista para a conduta humana e social, que estabelece um modelo de vida boa para a totalidade da sociedade.

Parece que esse confronto contemporâneo entre os partidários de uma ética das virtudes e os defensores de uma ética de princípios tem por base o estabelecimento de uma pretensa dicotomia. A ética das virtudes, que utiliza como critério de correção as ações (excelências) desejáveis socialmente, teria, assim, um modelo social, isto é, uma matriz comunitária, em que há uma comunidade com uma tradição moral, na qual o indivíduo (cidadão) está vinculado (particularismo), sendo virtuoso quando assume os valores dessa comunidade moral e vicioso, quando não os realiza. A ética dos princípios, que utiliza como critério de correção o dever universal, o qual obriga a todos os indivíduos que querem fazer parte da comunidade moral (hipotética), enquanto seres racionais e morais, teriam um modelo individual, isto é, uma matriz liberal, em que o indivíduo é considerado como responsável por sua escolha e ação, sendo autônomo, quando se auto-impõe a norma moral que é universal. Essas duas matrizes da ética são antagônicas ou complementares? Há algum motivo fundamental para serem vistas como tradições irreconciliáveis? Não seria desejável, em primeiro lugar, ver a possibilidade de um modelo ético que congregasse tanto a importância do comprometimento nas virtudes comunitárias como a relevância dos princípios universais e autonomia do sujeito? Respondendo afirmativamente à questão, creio que o segundo passo constitui-se em determinar se é possível encontrar algum modelo ético que se valha desta complementaridade.

Creio ser possível apontar em Aristóteles uma certa complementaridade entre uma ética das virtudes e uma ética dos princípios. Como Aristóteles é o autor par excellence recuperado contemporaneamente pelas atuais éticas das virtudes, que procuram contrapor-se às éticas principialistas, se for possível encontrar no interior de sua teoria das virtudes algum ponto de aproximação com o critério dado pelo princípio, então penso que se mostraria um local em que o diálogo se faz possível. Ao invés da batalha final entre os partidários das virtudes e os partidários dos princípios, teríamos um armistício, vislumbrando um possível foedus pacificum. O requisito essencial desaa hipótese seria encontrar no interior da análise de uma virtude moral um ponto de inflexão para o estabelecimento de princípios generalizantes ou universais, que estariam ligados ao caráter de correção moral perfeito, mas, entretanto, manteriam um certo distanciamento normativo. Ao que tudo indica, uma boa candidata para este teste seria a virtude da justiça

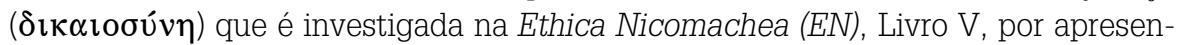
tar uma distinção entre justiça geral, que é identificada com a virtude e a justiça que é parte da justiça como virtude (justiça eqüitativa), que é elaborada na forma de princípios.

A investigação versará sobre o estatuto dos princípios da justiça, querendo saber se é possível identificar os princípios da diferença e da igualdade-liberdade 
como princípios universais, bem como os critérios da reciprocidade e da legalidade que afirmariam o que se deve fazer de forma absoluta e não como princípios

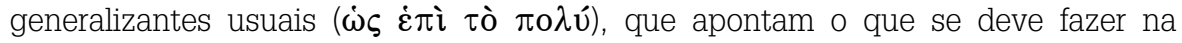
maior parte das vezes, como em EN I,3, IX,2 e V,10. Para tanto, inicio com a distinção realizada entre a justiça como moral privada ( justiça como moral pública (ı̋oos - igual) e, posteriormente, faço referência a uma certa independência procedimental na constituição dos princípios. Por fim, aponto para a inflexão em relação a uma reconciliação em direção à teoria das virtudes, ressaltando o papel da justiça natural como orientadora da justiça política, a tarefa da responsabilidade moral da ação voluntária, bem como a função corretora da

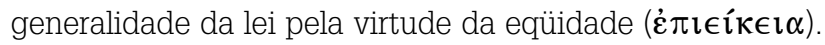

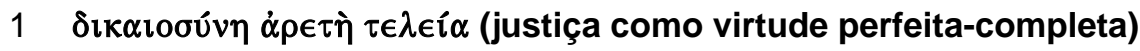

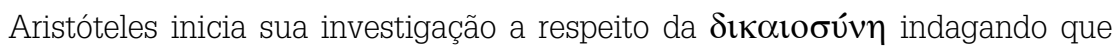

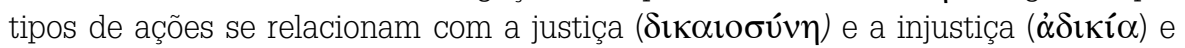
que tipo de mediania ( $\mu \in \sigma o ́ \tau \eta \varsigma)$ é a justiça, isto é, quer saber entre quais ações extremas se encontra o ato justo enquanto mesótês. A justiça está sendo considerada enquanto uma virtude ética, pois diz que a investigação proposta seguirá o mesmo $\mu \varepsilon ́ \theta o \delta o \varsigma$ percorrido anteriormente a respeito das outras virtudes éticas

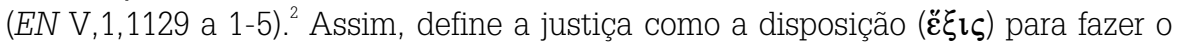
que é justo, agir de forma justa e, também, desejar o justo.

O que é identificado por Aristóteles é que os termos justiça e injustiça parecem ser utilizados em dois sentidos. O indivíduo injusto é aquele que transgride a

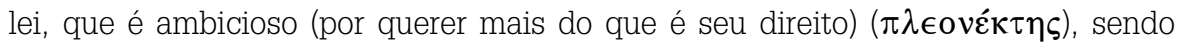

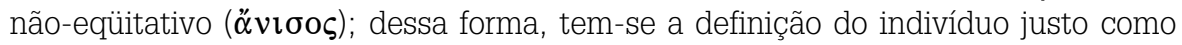
aquele que cumpre a lei correta (vó $\iota$ ı $\mu$ ov) e é eqüitativo, respeitando a igualdade (ไ̋ov). ${ }^{3}$ Através dessa determinação do justo e do injusto, chega-se, aqui, a uma primeira definição de justiça: "O justo, portanto, significa aquilo que é conforme à

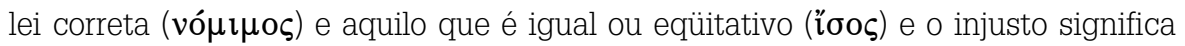
aquilo que é o ilegal ( $\pi \alpha \rho \alpha ́ v o \mu o v)$ e aquilo que é desigual ou não-eqüitativo (åvıoov)". ${ }^{4}$ Parece que Aristóteles já está estabelecendo uma sutil distinção entre a esfera do que é moral privada e o que é justo no sentido da moralidade pública. Aristóteles esclarece a respeito da confusão lingüística com que o termo justo era utilizado, apresentando uma homonímia (ó $\mu \omega v v \mu i ́ \alpha)$ : uns o utilizam para deter-

Utilizo o texto Ethica Nicomachea. Ed. I. Bywater. Oxford: Oxford University Press, 1894 (Reimp.1962). Também utilizo o texto MEPI $\Delta$ IKAIO $\Upsilon \Upsilon N H \Sigma$. The Fifth Book of the Nicomachean Ethics. By Henry Jackson. New York: Arno Press, 1973 (Publicado por Cambridge University Press, em 1879).

3 David Ross esclarece que o significado de justo como o que é conforme à lei não era interpretado como justiça, destacando que díkaios designava aquele que observava a regra correta (díkê), sendo posteriormente identificada com tudo o que é correto. Ver ROSS, David. Aristotle. London: Routledge, 1996, p. 215.

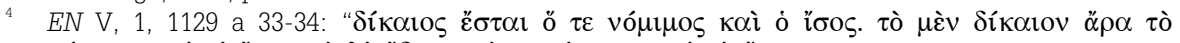

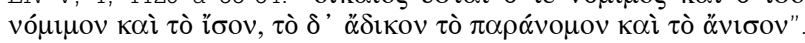




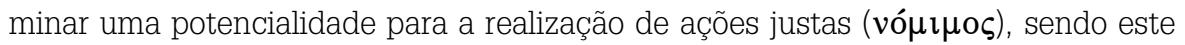
o campo da moral, e outros o utilizam para designar aquilo que é o igual (ไ̋oos) na distribuição dos bens da comunidade política. Essa homonímia revela que a palavra justiça é utilizada como sinônimo de moral, do que é correto, do que é bom moralmente, isto é, como vó $\iota$ น os, como o legal que teria um fundo moral, por ser uma síntese entre todas as virtudes morais. Mas a palavra justiça também é utilizada no sentido de igual, îoo $\varsigma$, no sentido em que o justo é cada um ter a sua parte correspondente, de forma igual e, por isso, o vício correspondente é querer tomar mais do que a sua parte ${ }^{5}$. A justiça geral representa uma virtude que propicia uma espécie de resumo das outras virtudes, ao ponto que possuir a justiça é possuir a virtude inteira. A partir dessa homonímia o caminho tomado é o da distinção entre a esfera da moral privada, em que a justiça é uma virtude que deve ser encontrada mediante o exercício individual para a determinação da $\mu \in \sigma o ́ \tau \eta \varsigma$

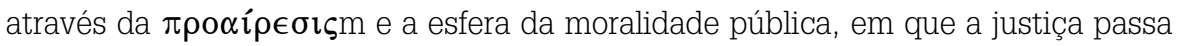
a significar proporção, a justa distribuição e correção, que será formulada na maneira de princípios. ${ }^{6}$

Os indivíduos que são ambiciosos são também não-eqüitativos, significando que querem simultaneamente muito as coisas boas e pouco as ruins, sem qualquer referência ao bem-estar da comunidade. A ação justa não pode ser movida

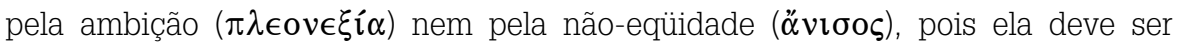
pautada pelo bem comum. Para Aristóteles, todos os atos que são praticados conforme a lei são justos em certo sentido, em função de o ato injusto ser caracterizado como aquele que infringe a lei e de os atos estipulados pela legislação serem conforme a lei (EN V, 1, 1129 b 11-14). ${ }^{7}$ Assim realiza uma identificação entre a justiça universal e o ordenamento legal, pois o que é determinado pela lei visa a atender ao interesse comum da comunidade política, tanto em relação aos interesses de todos os indivíduos quanto aos interesses de grupos específicos. Surge, assim, a definição da justiça como a mais perfeita virtude ética em função de ela estar identificada com a relação pública de todos os indivíduos, isto é, em função da especificação da forma de relação de uns com os outros, no momento em que

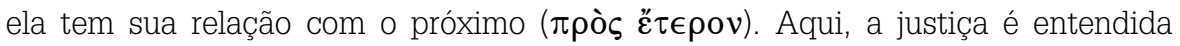

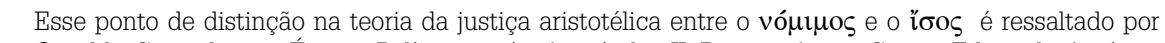
Osvaldo Guariglia em Ética y Política según Aristóteles II. Buenos Aires: Centro Editor de América Latina, 1992, p. 184

6 Conforme Montoya, a teoria da justiça aristotélica não pode ser interpretada como uma teoria puramente inclusiva do indivíduo à pólis, pois não está devidamente enquadrada no esquema geral eudemonista das virtudes. Aponta que pode ser interpretada a partir de critérios objetivos que afirmam a igualdade (isonomia) de todos os cidadãos, remetendo a uma forma democrática de vida política, não considerando a justiça em um modo virtuoso de ser do agente moral. Cf. MONTOYA, José, "Aristóteles: Justicia y Racionalidad Practica". In GÓMEZ; CASTRO, En Torno a Aristóteles, Santiago de Compostela, 1998, p. 258.

Ver o artigo de Bernard Williams sobre a pleonexía na EN V, "Justice as a Virtue". In: RORTY, Amélie (Org.). Essays on Aristotle's Ethics. Los Angeles: University of California Press, 1980, p. 189199. 
como a virtude ética que resume todas as outras virtudes, sendo a mais elevada e perfeita ( $\tau \in \lambda \in i \alpha \mu \alpha \dot{\lambda} \imath \sigma \tau \alpha)$ virtude ética (EN V, 1, 1129 b 29-31).

Aristóteles destaca que a justiça possui uma relação específica com o que é considerado um bem para as demais pessoas na comunidade política. Em comparação com as outras virtudes éticas, a justiça é a única que se identifica com o

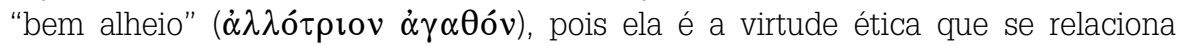

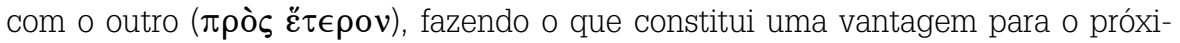
mo, tratando todas as pessoas como iguais, por serem todos membros da comunidade política (EN V, 1, 1130 a 3-4). Indica que a justiça não pode ser compreendida enquanto uma parte da virtude ética, mas deve ser entendida como a virtude ética total, e a injustiça, como seu contrário, deve ser entendida como a deficiência ética absoluta. No entanto, justiça será uma virtude ética específica que tem relação entre o eu e o outro na prática ético-política específica, e não somente em uma relação solipsista e subjetiva. O que se conclui dessa distinção é que, se a justiça tem relação com o "bem do outro", ela não pode ser entendida enquanto uma pura subjetividade, na qual individualmente eu decido sobre esse bem, em razão de o outro ter uma pretensão sobre esse bem, instituindo, assim, um caráter objetivo em que a ação moral já não estará entendida enquanto um meio individual, mas, sim, como um meio em relação à coisa de que o outro tem alguma pretensão. ${ }^{9}$

Essa distinção entre o dever, que tem relação com o bem alheio (em que o outro pretende algo) e o dever que somente tem uma relação subjetiva, conduz ao estabelecimento de uma diferenciação entre justiça e virtude ética. Para Aristóteles, justiça e virtude ética são a mesma coisa, porém a essência de ambas não é a mesma. ${ }^{10} \mathrm{~A}$ justiça é uma virtude ética que se pratica sempre em relação aos outros, sendo uma forma restrita de virtude ética, enquanto a virtude ética se compreende enquanto uma disposição irrestrita que pode ser realizada individualmente. Aristóteles abandona a antiga identificação de essência entre justiça e virtude ética utilizada por Platão, diferenciando entre a ação moral individual e a ação moral coletiva para o ordenamento público da comunidade política. Esse abandono de uma visão interiorizada de justiça, através da distinção entre virtude e justiça, possibilita pensar que na ética aristotélica encontra-se uma fundamentação da ação correta que vai além da autofinalidade da virtude, pois a justiça possui uma

Richard Bodéüs ressalta que uma das características que distingue a justiça das demais virtudes é que ela tem uma relação específica com os outros, enquanto outras virtudes têm uma relação puramente individual. As outras características destacadas são: que ela é uma virtude perfeita, que sintetiza as outras virtudes e que a justica particular não é uma mediania entre dois extremos. Cf. BODÉÜS, Richard. "La justice, état de choses et état d'âme". In: DESTRÉE, P. (Coord.). Aristote: Bonheur et Vertus. Paris: PUF, 2003, p. 136-8.

9 Segundo Höffe, deve corresponder ao caráter de dever o conceito mais objetivo de "meio segundo a coisa' e não ao conceito subjetivo de 'meio para nós'. Cf. HÖFFE, Otfried. "Aristóteles". In: RENAULT, A. História da Filosofia Política 1. Lisboa: Piaget, 2001, p. 144.

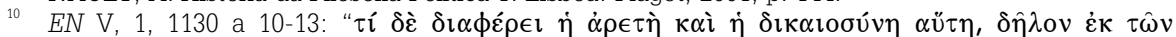

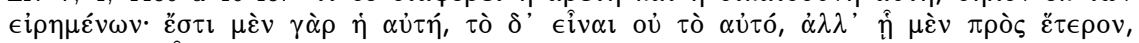

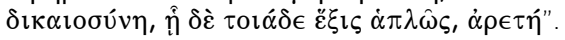


definição própria objetiva, independentemente do fato de constituir-se como uma virtude. Como Aristóteles está preocupado com a constituição da justiça para as questões de distribuição, não é razoável considerar que sua concepção seja teleológica no sentido de maximização de um bem particularizado, identificando o bem de forma independente do justo, pois, para a delimitação em relação ao bem alheio, o conceito de bem passa a ser considerado como abarcado pelo conceito de justo. ${ }^{11}$ É exatamente a partir dessa distinção que analiso a teoria da justiça aristotélica, não como estritamente vinculada a uma teoria teleológica das virtudes, mas que tem uma certa independência procedimental no estabelecimento de seus princípios públicos.

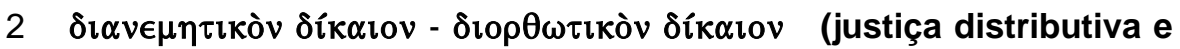 corretiva)}

A distinção entre a teoria da justiça e a teoria das virtudes fica mais clara a partir do início do V, 2 da $E N$, em que há o destaque de que o objeto específico de investigação será a justiça eqüitativa ( $\mu \varepsilon ́ \rho \circ \varsigma$ - que é parte da justiça como virtude), isto é, no seu sentido político-jurídico, e não a justiça compreendida enquanto totalidade das virtudes (EN V, 2, 1130 a 14-16). ${ }^{12}$ Percebe-se claramente que a injustiça particular não está diretamente relacionada com todos os vícios como "covardia, cólera, mesquinhez", mas, sim, com os vícios que possuem relação com tomar mais do que a parte que cabe a cada um $(\pi \lambda \in o v \in \kappa \tau \in \hat{\imath})$. Com isso, identifica que a injustiça em questão tem relação com o tomar demais do que é a parte correspondente de um bem público e essa ação não possui uma relação direta com os outros vícios privados, apontando para a circunscrição da esfera da justiça ao âmbito político-jurídico, de forma a identificar o injusto como tendo relação com o desigual, isto é, ao não-eqüitativo, indo além do injusto no sentido de ilegal (que não cumpre a lei correta). Tem-se, então, a identificação da justiça com o ordenamento político-jurídico que estabelece critérios mais fortes para a convivência societária do que somente a deliberação subjetiva do indivíduo. Para ressaltar seu posicionamento, Aristóteles exemplifica a questão com o caso do adultério: um comete o adultério em razão de um lucro e outro o comete em função do desejo. O indivíduo que comete o adultério por desejo não é injusto, mas apenas concupiscente (desregrado), enquanto o que comete por intenção do lucro é injusto, não sendo vicioso moralmente, em que o ato injusto significa alguém lucrar em uma situação em que lesa o outro. A conclusão que é inferida do exemplo citado é

\footnotetext{
${ }^{1}$ Penso que a teoria da justiça de Aristóteles adota uma concepção teleológica desse tipo, em que o bem é identificado em relação à distribuição dos bens da pólis a partir dos princípios de justiça, a saber, a partir da igualdade-liberdade e da diferença. Cf. a esse respeito NUSSBAUM, Martha. The Fragility of Goodness. Cambridge: Cambridge University Press, 1986, p. 433-434.

12 Uso a expressão "justiça eqüitativa" como similar à "justiça particular", por se tratar da justiça que toma como critério a igualdade (ísos) para a distribuição dos bens, como faz, também, Richard Kraut: "But the second half - dikaiosun as equality or fairness" (KRAUT, Richard. Introduction. Guide to Aristotle's Nicomachean Ethics. Oxford: Blackwell Publishing, 2006, p. 7).
} 
que a justiça tem relação com as regras públicas de relacionamento e não com as regras privadas de convivência, abrindo um espaço para a afirmação da necessidade do direito universal, não identificando diretamente o bem que é público com o bem que é particularizado.

Aristóteles procura esclarecer que as questões de justiça estão identificadas com a relação intersubjetiva dos indivíduos, pois elas se relacionam com a "honra

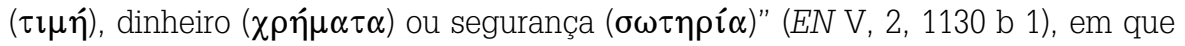
a injustiça é caracterizada com o prazer do ganho, sendo que um outro sofre uma perda. Isso significa que a justiça não tratará do aspecto legal-moral (vó $\mu$ ı $\mu$ ov) e, sim, do aspecto eqüitativo (ไ̌oov), pois aquilo que fere a eqüidade é também ilegal. O objeto central da teoria da justiça é a garantia de eqüidade nas relações

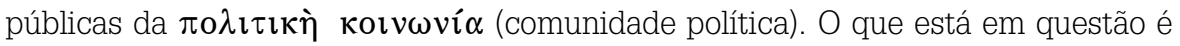
a determinação de um critério universal racional de igualdade para estabelecer a distribuição eqüitativa dos bens públicos, bem como poder intermediar as situações de conflito nas relações privadas. Aqui parece que não se encontra a utilização de princípios generalizantes usuais, que dizem o que se deve fazer na maior parte das vezes ( $\dot{\omega} \zeta \dot{\varepsilon} \pi \grave{\imath} \tau o ̀ ~ \pi o \lambda u ́)$, em que há a identificação de que um bom número de As são B, como é apresentado em $E N$ I,3,1094 b 21, mas a utilização de princípios universais, na forma em que todo A é B. ${ }^{13}$

Creio que essa teoria estabelece um distanciamento de uma visão perfeccionista de justiça, na qual se identifica o papel do Estado com uma função específica de criar homens bons (virtuosos). Aristóteles aponta que na concepção privada de justiça que está anexada à teoria das virtudes, se estabelece uma associação com as ações permitidas pela lei (recomenda a virtude) e, sendo assim, deve existir uma educação correspondente, visando à criação do homem virtuoso

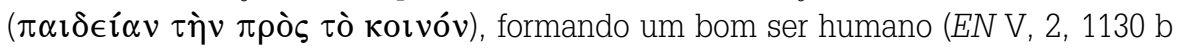
27). No que diz respeito à educação do indivíduo enquanto tal ( $\dot{\alpha} v \grave{\rho} \rho \dot{\alpha} \gamma \alpha \theta$ ós), a questão central não se encontra na formação do bom ser humano $(\dot{\alpha} \gamma \alpha \theta \hat{\omega})$, mas na formação do homem enquanto cidadão $\left(\pi \circ \lambda i\right.$ in). ${ }^{14} \mathrm{O}$ que vai ser concluído é

${ }^{13}$ Essa regra generalizante pode ser formulada da seguinte maneira: na maior parte dos casos $(\dot{\omega} \varsigma$

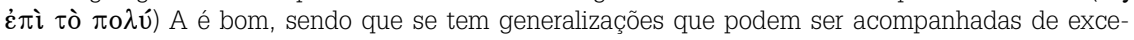
ções, não se encontrando, aqui, uma dedução de uma lei universal de tipo para todo X, A é bom. Essa regra admite exceções, porém essa especificidade não significa um impedimento de cientificidade que aponta para o verdadeiro. Veja-se o exemplo das concepções de bem estarem inscritas na esfera da incerteza em função de coisas boas poderem ter algum efeito nocivo, como o caso de a riqueza e a coragem poderem destruir a vida dos indivíduos (EN I, 31094 b 18-19). Dizer que a riqueza ou a coragem são um bem, na maior parte das vezes, é dizer que elas são um bem, mesmo que em alguns casos elas sejam nocivas. A essa aparente indeterminação, parece que se aponta para a conclusão de que, nos casos em que a riqueza e a coragem se constituirem como nocivas, elas não podem ser consideradas como bens. Isso significa que as generalizações em ética devem ser acompanhadas de qualificações, isto é, devem estar acompanhadas de referências objetivas em relação ao objeto específico. Cf. IRWIN, T.H. "A ética como uma ciência inexata" (Analytica, Rio de Janeiro, 1/3 (1996), p. 50)), em que ressalta o papel normativo dos princípios generalizantes usuais.

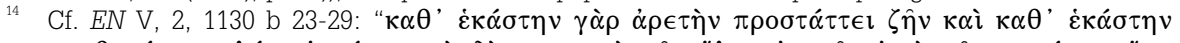

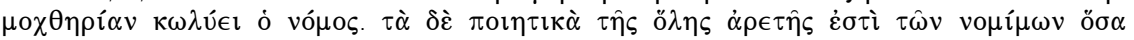

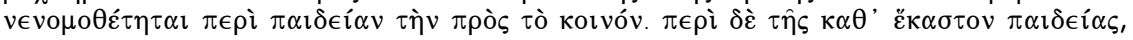


que não existe uma identidade absoluta entre um bom ser humano e um bom cidadão, revelando que a esfera pública de justiça não necessita de uma visão perfeccionista de homem para o estabelecimento de critérios a respeito da eqüidade na sociedade política, podendo a justiça ser alcançada por cidadãos e não necessariamente homens virtuosos.

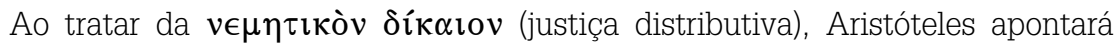
para que tipo de mediania corresponde ao ato justo, em que se deve especificar de que maneira se realiza essa operação de mesótês, a saber: se da mesma forma que as outras virtudes, ou se utiliza um mecanismo diferenciado. Aponta que nas coisas relacionadas com os bens públicos que serão distribuídos, a injustiça

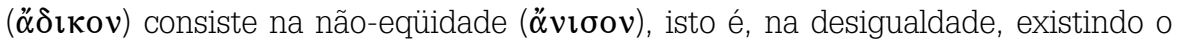
mais e o menos e, portanto, o justo será a mediania ( $\mu \varepsilon ́ \sigma o v)$ entre o mais ( $\pi \lambda \dot{\varepsilon} o v)$ e o menos ("̌ $\lambda \alpha \tau \tau o v$ ), isto é, o igual (ไ̌oov). Sendo que o igual é uma mediania

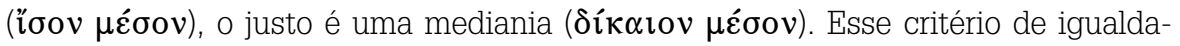
de está sendo enunciado por Aristóteles como uma assertiva que não possui ne-

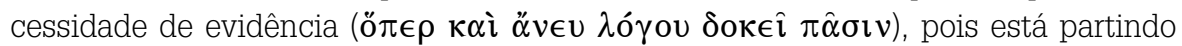
de um critério matemático universal no qual, se há desigualdade entre os indivíduos e os bens da distribuição, o justo será aquilo que proporcionará a igualdade (EN V , 3, 1131 a 11-15). Esse critério de igualdade implica, no mínimo, dois termos, nos quais se identifica que o justo seja uma mesótês e seja o igual (relativo ao justo para os indivíduos); na qualidade de mesótês, implica sobre certos extremos que são o mais e o menos; na qualidade de igual, deve implicar em duas proporções que são iguais; na qualidade de justo ele envolve determinados indivíduos em relação aos quais é justo. Disso Aristóteles infere que a justiça envolve quatro termos, sendo: dois indivíduos para os quais existe a justiça e duas proporções que são justas. A regra da justiça distributiva fica sendo que a igualdade deve ser proporcional, de forma que a proporção entre as parcelas de bens a serem distribuídas deve corresponder à proporção entre os indivíduos, concluindo-se que, se os indivíduos não forem iguais, não receberão porções iguais dos bens (EN V, 3, 1131 a 27-31). Com isso, tem-se a formulação do Princípio da Diferença: a regra da justiça distributiva é formulada como uma igualdade proporcional

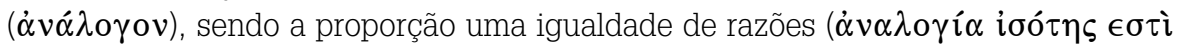

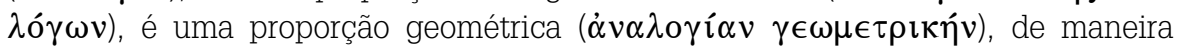
que a proporção entre as parcelas de bens públicos deve ser correspondente à proporção entre os indivíduos, não sendo os indivíduos iguais, não receberão parcelas iguais dos bens. ${ }^{15}$

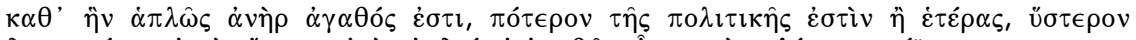

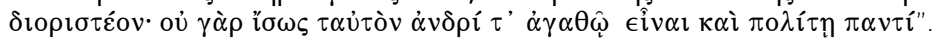

15 Procedimento da justiça distributiva: 1)Identificação do bem: a distribuição dos bens públicos; 2) Fundamentação do Princípio de Justiça: critério matemático de igualdade; 3) Procedimento: 3.1- A igualdade envolve dois termos, significando: 3.1.1- que o justo seja uma mediania e igual, sendo relativo ao que é justo para determinados indivíduos, 3.1.2- como uma mediania, coloca-se entre o mais e o menos, 3.1.3- como igual, implica duas proporções que são iguais, 3.1.4- como justo, ele envolve determinados indivíduos em relação aos quais é justo; 3.2- Disso Aristóteles conclui que a 
Esse princípio da diferença é formulado a partir de uma compreensão do que é a distribuição eqüitativa dos bens públicos, fundamentada em um critério matemático de igualdade (proporção geométrica) através de um procedimento racional para designar o que é o justo (igualdade proporcional). A justiça distributiva é uma $\mu \epsilon \sigma o ́ \tau \eta \varsigma$ independente do entendimento individual do agente moral que

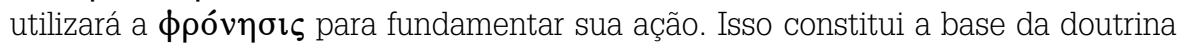
eudemonista das virtudes, utilizando, ao invés da subjetividade que tem a norma como referência, um critério objetivo para a determinação do justo, tendo um sentido público que se distancia de um modelo de racionalidade prática privada.

A segunda espécie de justiça eqüitativa é identificada por Aristóteles como

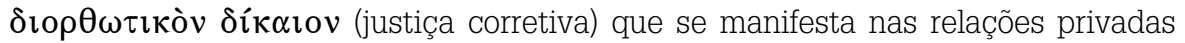

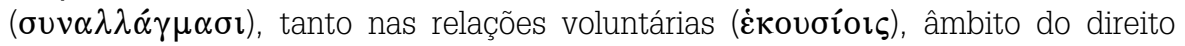

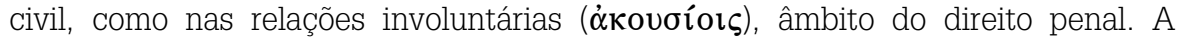

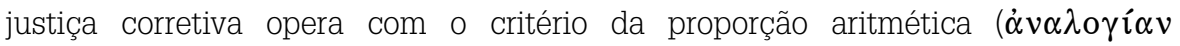
$\dot{\alpha} \rho \imath \theta \mu \eta \tau \imath \kappa \eta v v)$, na qual o critério continua sendo o da igualdade, porém ela não segue a proporção geométrica, pois o que é fundamental nesse tipo particular de justiça é restabelecer a igualdade que foi rompida de forma universal. Aqui, o critério utilizado é o da igualdade de todos perante a lei, não sendo relevante a qualidade moral dos indivíduos nesse tipo de relação (se são bons ou maus), pois o que se destaca como essencial é que a lei contempla apenas o aspecto distintivo da justiça, tratando as partes como iguais. ${ }^{16}$

É possível encontrar, dessa maneira, a defesa clara da ioovo $\mu i ́ \alpha$ como critério universal da justiça nas relações dos cidadãos em sua esfera privada, isto é, identifica-se a igualdade de todos perante a lei, estabelecendo o critério do 'igual para iguais', no qual se encontra uma defesa incondicional das liberdades subjetivas pela garantia legal da igualdade de todos. Parece ficar evidente que Aristóteles está tratando a justiça não como uma virtude, mas enquanto princípio, que tem uma função equalizadora, estabelecendo uma certa fronteira entre a moralidade privada e pública.

Esse afastamento da justiça corretiva ao âmbito da moral privada fica evidenciado a partir da associação desse tipo de justiça com a função do juiz ( $\delta \iota \kappa \alpha \sigma \tau \eta ́ \varsigma)$, sendo o juiz a justiça personificada, porque é como uma mediania entre as partes que estão em desacordo, oferecendo uma mediação entre aqueles que reclamam a respeito da perda e do ganho, tendo a função de restituição da

justiça envolve quatro termos: 3.2.1- dois indivíduos para os quais existe a justiça, 3.2.2- duas proporções que são justas; 4) Formulação do Princípio da Diferença: a regra da justiça distributiva é formulada como uma igualdade proporcional, de maneira que a proporção entre as parcelas de bens públicos deve ser correspondente à proporção entre os indivíduos.

16 Segundo Aubenque, a justiça corretiva possui uma determinação matemática na igualdade, em que o que é essencial é a realização de uma equalização entre o que agiu injustamente e o que sofreu a ação injusta. O argumento ressalta que a igualdade de todos perante a lei estabelece uma esfera da vida privada em que todos são iguais, isto é, na qual todos possuem os mesmos direitos e, com isso, os indivíduos têm resguardada sua liberdade. Cf. AUBENQUE, Pierre. "Aristote etait-il communitariste?" In: GÓMEZ; CASTRO. En Torno a Aristóteles. Santiago de Compostela, 1998, p. 41. 
igualdade rompida ( $E N$ V , 4, 1132 a 21-26). A justiça é entendida enquanto uma medida mediana entre as partes disputantes, da mesma forma que o juiz estabelece essa mediania através da restauração da igualdade, em que sua função é a subtração do segmento maior daquela parte que excede o meio, somando à parte menor para restituir o meio (pensando em uma linha dividida em duas partes desiguais, o juiz restaura a igualdade através da equalização das linhas), sendo o igual uma mediania entre o mais e o menos conforme uma proporção aritmética (EN V, 4, 1132 a 26-34). Isso possibilita apontar para a utilização do critério da imparcialidade como condição necessária para a justiça, estabelecendo um certo distanciamento correto para proceder ao julgamento.

A questão central, então, é o estabelecimento de um procedimento justo para a determinação da igualdade nessas situações em questão. O ponto de partida é a utilização de um critério matemático universal da igualdade segundo uma proporção aritmética, em que: considerando duas partes iguais (A e B); se uma porção é retirada de $A$ e colocada em $B$, tem-se que $B$ excederá $A$ duas vezes aquela parte subtraída; então, deve-se subtrair o excesso de B (que ultrapassa a igualdade) e restituir a A para recompor a igualdade. Tem-se, assim, a formulação do Princípio da Igualdade-Liberdade: a regra da justiça corretiva é formulada como uma igualdade aritmética, na qual todos os indivíduos são considerados como iguais perante a lei (íoovouí $\alpha$ ), o que garante, por sua vez, a liberdade negativa. ${ }^{17} \mathrm{O}$ que se destaca é a defesa incondicional da ioovouí $\alpha$ na justiça corretiva que opera com um princípio de universalidade, pois sua tarefa é a garantia da liberdade e da igualdade na sociedade, atuando de forma necessária e absoluta, servindo como critério fundamental para regular a justiça distributiva em um horizonte procedimental e público. ${ }^{18}$

O procedimento utilizado para o estabelecimento dos princípios de justiça é o da eqüidade na comunidade política, em que os membros da pólis têm que pensar o que é justo na esfera pública, de forma a assegurar a todos a igualdade legal que assegura a liberdade e, também, a possibilidade de resgate de uma desigualdade no interior da comunidade, através da garantia da diferença para o restabeleci-

17 Procedimento da justiça corretiva: 1) Identificação do Bem: a justiça nas relações privadas; 2) Fundamentação do Princípio de Justiça: critério matemático universal de igualdade; 3) Procedimento: 3.1- Ponto de Partida: a igualdade é uma mediania entre o maior e o menor através de uma proporção aritmética, 3.1.1- Considerando duas partes iguais A e B, 3.1.2- Se uma parte é retirada de A e colocada em B, tem-se que B excederá A duas vezes aquela parte subtraída, 3.1.3- Deve-se, então, subtrair o excesso de B (que ultrapassa a igualdade) e restituir a A para recompor a igualdade; 4) Formulação do Princípio da Igualdade: a regra da justiça corretiva é formulada como uma igualdade aritmética, na qual os indivíduos são como iguais perante a lei.

18 Essa interpretação da teoria da justiça de Aristóteles em um contexto aproximativo com as modernas teorias da justiça e direitos humanos é realizada de maneira exemplar por Fred Miller. Ele defende que a teoria aristotélica não considera apenas a justiça como virtude, mas que elabora princípios formais de justiça ('formal' principles of justice) baseados na eqüidade, igualdade e reciprocidade: "Aristotle's treatise on justice deals not only with the virtues of justice, but also with what might be called 'formal' principles of justice, i.e, abstract principles admitting of different, correct as well as incorrect, applications" (MILLER, Fred. Nature, Justice, and Rights in Aristotle's Politics, Oxford: Oxford University Press, 2001, p. 68). 
mento da igualdade. Mesmo que a fundamentação da eqüidade tenha partido de um critério universal matemático (geométrico e aritmético), é no interior da

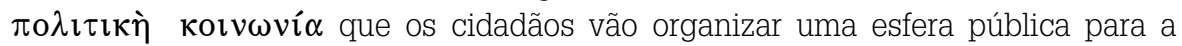
garantia da eqüidade, estruturando a justiça como uma condição de possibilidade para a eudaimonía. Como a justiça eqüitativa se entende como uma condição de possibilidade da comunidade política para a efetivação dos planos racionais de vida (individuais), ela estabelece o critério da igualdade e da diferença. Dessa maneira, considera os cidadãos de uma maneira formal, abstrata, considerando todos iguais perante a lei, sem diferença de mérito ou casos particulares e, também, considera os cidadãos como entes concretos, com suas particularidades, na observação das diferenças de necessidade, mérito ou participação, levando em consideração as situações desiguais, identificando a independência do indivíduo frente à polis. ${ }^{19}$ Penso não ser possível identificar esse modelo de teoria da justiça como puramente teleológico e substancial porque os princípios não foram estabelecidos a partir de uma idéia de bem descolada da esfera pública, mas, sim, foram estabelecidos a partir de um critério matemático universal na práxis política a partir do raciocínio do que seria necessário garantir no âmbito público, em termos iniciais, para a efetivação da eqüidade na pólis, pois a teoria da justiça (particular) visa à criação de um sistema eqüitativo de cooperação social, sendo entendida enquanto essencialmente política, que possui a finalidade de estabelecer os princípios eqüitativos para a convivência política e social.

Como conclusão, pode-se dizer que os princípios da diferença e da igualdade-

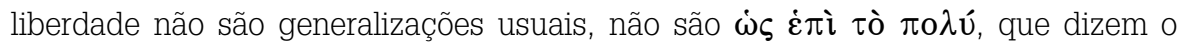
que é justo na maior parte das vezes, mas possuem uma força maior de obrigação, pois dizem que o justo é sempre ora uma proporção geométrica ( $\alpha$ vá $\lambda$ o $\gamma i ́ \alpha \nu$

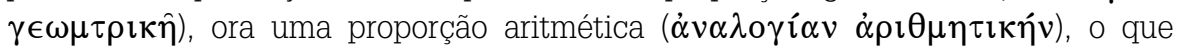
possibilita apontar para a universalidade desses dois princípios da justiça. Parece que o modelo da ética aristotélica se constrói em um ambiente de complementari-

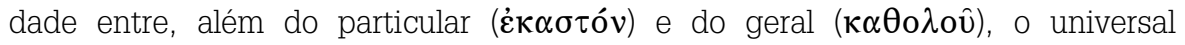

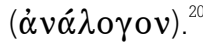

${ }_{19}$ Charles Young conclui seu artigo sobre a justiça em Aristóteles, apontando que a justiça particular está circunscrita às relações com os outros, em que se assume a perspectiva do outro como membro da comunidade de seres humanos livres e iguais, isto é, como cidadãos, que são membros livres e iguais da comunidade política. Ver YOUNG, Charles. "Aristotle's Justice". In KRAUT, R. (Ed.). The Blackwell Guide to Aristotle's Nicomachean Ethics. Oxford: Blackwell Publishing, 2006, p. 196.

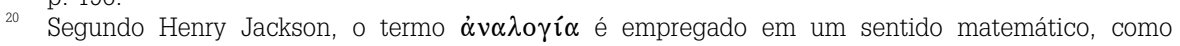
equivalente do termo proporção, que estabelece uma relação de equivalência entre duas outras relações, como no modelo: A está para B, assim como C está para D. Está proporção pode ser verificada em três sentidos: geométrico, aritmético, recíproco, o que corresponde aos três tipos particulares de justiça: justiça distributiva (proporção geométrica), justiça corretiva (proporção aritmética), justiça comercial (proporção na reciprocidade). Ver nota 5, em que esclarece sobre o termo $\dot{\alpha} \nu \tau \imath \pi \in \pi$ ov $\theta$ ó $\varsigma$ (JACKSON, Henry. The Fifth Book of the Nicomachean Ethics. New York: Arno Press, 1973, p. 87). 


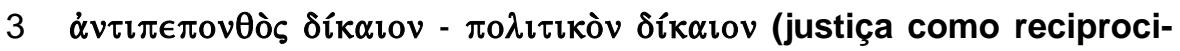 dade e justiça política)}

Além da justiça distributiva e da justiça corretiva, Aristóteles identifica a justiça como reciprocidade (comercial) como um terceiro tipo de justiça particular que utiliza como critério essencial a reciprocidade proporcional, visando à garantia da união da pólis nas trocas comerciais, corroborando com o argumento de que a teoria da justiça não está sendo desenvolvida na esfera da ética das virtudes. Na interpretação aristotélica não é possível concordar com a identificação do critério de reciprocidade ( $\dot{\alpha} v \tau \imath \pi \in \pi$ ov $\theta$ ós) com a justiça universal, devendo-se fazer a A aquilo que ele fez a B, da maneira que era compreendida pela escola pitagórica e, também, não é possível relacionar o critério de reciprocidade com a justiça distributiva e nem com a justiça corretiva, ${ }^{21}$ mesmo que, na interpretação cotidiana, a justiça corretiva seja compreendida como uma regra que imputa ao agente sofrer igualmente o que infligiu ( $E N$ V, 5, 1132 b 25-26). Somente nas trocas comerciais é que se deve utilizar o critério da reciprocidade proporcional, de forma a possibilitar a união da polis. ${ }^{22}$

A justiça como reciprocidade ocorre nas relações voluntárias (atos voluntários), sendo que nas associações que têm por objetivo a troca comercial (troca de serviços), os indivíduos permanecem unidos em função da reciprocidade proporcional que une a comunidade em relação ao seu comércio ( $E N \mathrm{~V}, 5,1132$ b 31-36). Aristóteles identifica que nas trocas comerciais, deve-se respeitar a justiça sob a

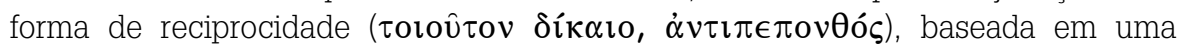

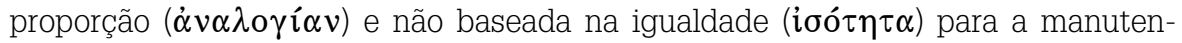
ção do vínculo da comunidade, isto é, nas associações que visam à troca de serviços, os indivíduos se mantêm unidos pela reciprocidade com base na proporcionalidade, e não baseados em uma retribuição exatamente igual, pois é a reciprocidade proporcional que possibilita a coesão da pólis (EN V, 5, 1133 a 1-6). É em razão disso que o critério de reciprocidade proporcional deve ser efetivado através de

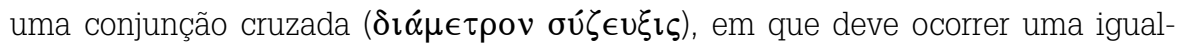
dade proporcional dos bens que serão trocados, de forma que um produtor deve obter em uma troca, o produto proporcional oferecido por seu próprio trabalho ( $E N$ V, 5, 1133 a 10-16). Dessa forma, os serviços que estão em relação na sociedade devem ser comparáveis de alguma forma, pois em uma situação em que o produto de um dos participantes da troca for melhor que um outro produto, os produtos devem ser equalizados. Para essa finalidade, foi criado o dinheiro (vó $\mu \iota \sigma \mu \alpha)$, que

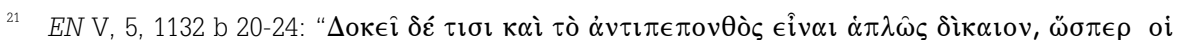

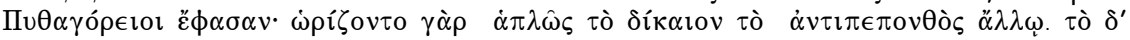

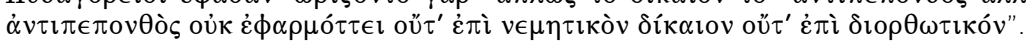

22 Sarah Broadie, em sua introdução (Philosophical introduction) da tradução da Nicomachean Ethics, feita por C. Rowe (2002), interpreta a justiça comercial (commercial exchange) como um tipo especial de justiça, que utiliza como critério a reciprocidade (reciprocity) nas trocas comerciais da comunidade política, com a finalidade de garantir a união da pólis. Cf. BROADIE, Sarah. In: Aristotle. Nicomachean Ethics. Philosophical introduction and commentary by Sarah Broadie. Oxford: Oxford University Press, 2002, p. 37. 
é, em um certo sentido, uma mediania ( $\mu \varepsilon ́ \sigma o v)$, pois ele serve para igualar os produtos desiguais, sendo uma mediania entre os excessos de mais ou menos valor de um produto (EN V, 1133 a 26-31). O que parece estar sendo identificado é que é necessário utilizar-se de um padrão para medir as mercadorias que são desiguais, e esse padrão é oferecido pela $\chi \rho \in i ́ \alpha$ (demanda ou utilidade), pois se constitui naquilo que oportuniza as relações comerciais. Dessa maneira, o critério que será utilizado para estabelecer a medida entre os diversos tipos de mercadorias é a demanda (utilidade), a qual é um fator que mantém a coesão da pólis, e o dinheiro é considerado como uma espécie de representante da demanda, sendo criado para evitar as flutuações de valor e de troca ( $E N$ V, 5, 1133 a 37-44). O dinheiro assume a função de estabelecer a equalização entre os diversos produtos produzidos que são desiguais, isto é, ele é entendido como uma mediania entre o excesso e a deficiência que tem a tarefa de estabelecer a eqüidade nas trocas comerciais, servindo para o estabelecimento de trocas futuras, estando também sujeito a uma flutuação de valor, porém, em muito menor escala que as demais mercadorias. Essa concepção de justiça não é substancial, pois não trata do valor justo das mercadorias nas trocas comerciais, pelo contrário, ela aponta que se alcança a eqüidade nas compras e vendas pela utilização do padrão da demanda, isto é, da utilidade que os indivíduos identificam nas mercadorias. A demanda $(\chi \rho \in i ́ \alpha)$ é o procedimento que possibilita a justiça nessas relações comerciais.

Acredito que a questão que se revela como essencial para Aristóteles é a identificação do tipo de justiça relacionado com a esfera pública, ficando em segundo plano a justiça do ponto de vista moral (como virtude), pois é este o objeto específico da investigação que se constituirá na análise da justiça política

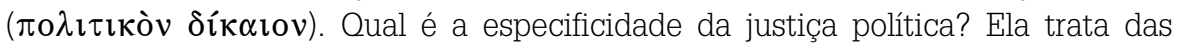
relações (de justiça) públicas entre indivíduos que são considerados livres

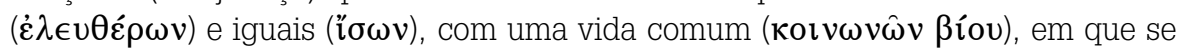
busca a satisfação das necessidades para a realização da auto-suficiência $(\alpha$ ủ $\alpha \hat{\rho} \kappa \in \iota \alpha){ }^{23}$ Aqui está a definição da justiça política: ela está circunscrita nas relações sociais, políticas e econômicas com o objetivo específico de garantir a auto-suficiência do grupo, isto é, de garantir a auto-suficiência de indivíduos livres e iguais, proporcionalmente ou aritmeticamente. ${ }^{24}$ Aristóteles está delimitando a esfera da justiça política como tendo relação ao ordenamento legal da comunidade política, pois a justiça só é possível entre os indivíduos livres e iguais que possuem suas ações reguladas pela lei (vó $\boldsymbol{L}_{\boldsymbol{0}}$ ), sendo que é questão primordial para a lei a classificação do justo e do injusto, em que a ação injusta tem relação com o apropriar-se de uma parcela grande de coisas boas ( $\dot{\alpha} \pi \lambda \hat{\omega} \varsigma \dot{\alpha} \gamma \alpha \theta \hat{\omega} v)$ e, também,

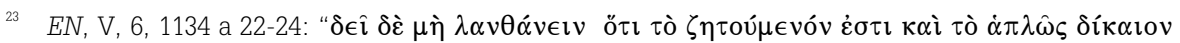

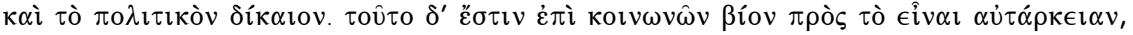

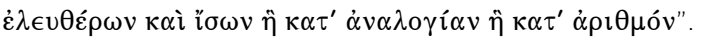

${ }^{24}$ Segundo a $E N \mathrm{~V}, 6,1134$ a 26-29, a justiça política pode ser considerada uma justiça particular, pois ela só é existente entre indivíduos que possuem suas relações mútuas regidas pela lei, sendo que a lei estabelece o impedimento da injustiça, na medida em que discrimina o que é justo ou injusto. 
de uma parcela pequena de coisas ruins ( $\dot{\alpha} \pi \lambda \hat{\omega} \varsigma \kappa \alpha \kappa \hat{\omega} v)(E N \mathrm{~V}, 6,1134$ a 26 $1134 \mathrm{~b} 4)^{25}$

O ponto central é a identificação dos atos específicos de injustiça cometidos pelos indivíduos que estabelecem uma convivência comum: a ação injusta se constitui na atribuição demasiada de coisas boas a si mesmo, com a exclusão de coisas ruins. O argumento desenvolvido por Aristóteles é que em uma comunidade humana, na qual se identificam diversos interesses particulares a partir das relações políticas e sociais, a ação injusta, que consiste na apropriação indevida de coisas boas (com a exclusão das más), deve ser coibida pela leiesta deve consistir em uma garantia da liberdade e da igualdade, tanto do ponto de vista aritmético quanto do ponto de vista geométrico, isto é, a lei deve garantir o princípio da igualdade/liberdade e o princípio da diferença. É por isso que, nas relações públicas, quem deve possuir primazia é a lei e não um indivíduo isolado, para evitar que se crie uma ordem pública com base apenas na vontade de um indivíduo. Dessa maneira, na teoria da justiça aristotélica, a lei assume um papel essencial, na tentativa de garantir a liberdade e a igualdade a partir de um reconhecimento do grupo social, evitando a fundamentação da ordem justa em um só indivíduo (governante), que fará sua deliberação a partir, apenas, de sua vontade (subjetividade) ou de seus interesses particulares. Por isso, Aristóteles fala que o governante deve ser aquele que atua no sentido de estabelecer uma ação política a partir da justiça, não devendo comandar a comunidade política em razão de sua subjetividade, de forma a ser compreendido como o "guardião da justiça" ( $\phi \dot{\nu} \lambda \alpha \xi$

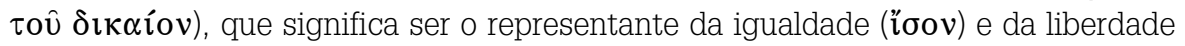
no sentido de que ele deve obedecer ao que está prescrito na lei, efetivando e garantindo os direitos e deveres estabelecidos na lei ( $E N \mathrm{~V}, 6,1134$ b 4-8).

Mesmo com esta diferenciação dos âmbitos moral e político da justiça, é importante frisar que não há uma distinção irreconciliável entre a justiça enquanto virtude e a justiça enquanto princípios, isto é, enquanto critérios normativos político-jurídicos. Parece existir uma complementaridade entre virtudes e princípios, considerando os princípios como uma outra face das virtudes, face esta que se caracteriza por uma maior obrigação por estar circunscrita à esfera pública. Essa complementaridade pode ser percebida na análise da justiça política, em que são tratadas três questões relevantes, a saber: o significado da justiça natural, da responsabilidade individual e da eqüidade ( $\dot{\varepsilon} \pi \imath \in \hat{\imath} \kappa \in \mathfrak{l} \alpha)$ na teoria da justiça.

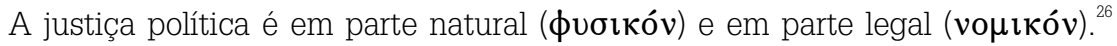
Aristóteles estabelece uma distinção entre o direito natural e o direito positivo, em que o que é justo por natureza se apresenta como universal, isto é, como tendo validade universal, não dependendo da concordância dos indivíduos da comunidade, e o que é legalmente justo tem um caráter convencional, particular,

${ }^{25}$ Esta análise da justiça política também é encontrada em Política (Pol.) III, 9, 1280 a 17-20; 12, 1282 b 17-21; 13, 1283 a 39-40).

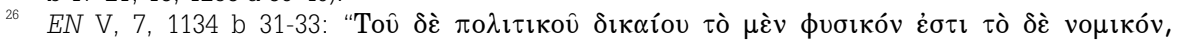

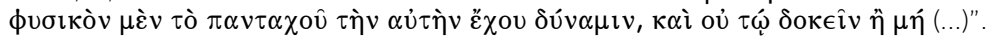


podendo ser estabelecido, a partir do entendimento particular dos envolvidos ( $E N$, V, 7, 1134 b 31-34). Uma questão central é a de saber se a justiça política utilizará apenas uma fundamentação substancial baseada na natureza ou se é possível perceber um espaço de indeterminação para a construção dos princípios de justiça.

O problema evidenciado é que usualmente a teoria da justiça aristotélica é interpretada como uma concepção baseada na justiça natural, com a finalidade de oferecer um ordenamento correto (universal) para as leis positivas, de forma a ter

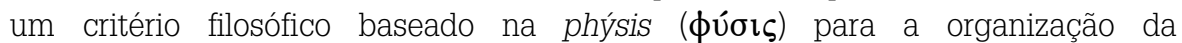
comunidade política. Nessa interpretação, ela utiliza como critério ideal a concepção de natureza para legitimar o justo, utilizando um critério imutável (cosmológico) para a determinação da justiça de maneira independente da razão do sujeito, revelando um modelo substancial de justiça, em que esse direito natural (que é objetivo) não é deduzido da razão humana, mas identificado em uma ordem imutável. Abandonando esse modelo de análise, quero apontar que a teoria da justiça de Aristóteles, além de substancial, utiliza-se de um modelo procedimental, porque: 1) o direito positivo não é deduzido do direito natural e nem se opõe a ele, antes, a justiça política se constrói no espaço em aberto deixado pelo direito natural que não determina todas as ações e 2) o direito natural é apenas uma idéia orientadora para o direito positivo, não sendo determinante deste.

Para Aristóteles é equivocado pensar que toda a justiça política é convencional (legal), por ser mutável. Para ele existe uma parte da justiça política que é natural, tendo a mesma força em todos os lugares, sendo universal em relação à particularidade da convenção ( $E N$ V, 7, 1134 b 40-43). Aristóteles não concorda com o entendimento dos sofistas, os quais evidenciavam que as regras de justiça seriam apenas convencionais, por isso, ressalta a relevância de utilizarse como um princípio ordenador a justiça natural, com validade universal. Mesmo identificando a relevância substancial do direito natural, Aristóteles aponta para o problema da diversidade das comunidades políticas e a necessidade da convenção para o estabelecimento de princípios ( $E N$ V, 7, 1134 b 43-46), não estabelecendo princípios jurídicos universais para a fundamentação do direito positivo. ${ }^{27}$ Ademais, não é apenas o direito positivo que é mutável, também o direito objetivo, sendo natural, seria tão mutável quanto a própria ordem da natureza em função de sua submissão ao movimento (EN V, 7, 1134 b 47-51). Ao que tudo indica, o direito positivo (justo legal) não está sendo deduzido de forma absoluta do direito natural e nem está se construindo em oposição a este: o direito positivo se constitui no espaço deixado em aberto pela justiça natural que não determina todas as ações. A justiça política é constituída nesse espaço de indeterminação,

\footnotetext{
Segundo Höffe, o direito natural, em Aristóteles, determina dois critérios, a saber, a universalidade e a não-arbitrariedade; porém, não se verifica a instituição de princípios jurídicos universais em substituição do direito positivo. A justiça natural oferece uma fundamentação moral do direito (HÖFFE, 1998, p. 149).
} 
possibilitando que os diversos povos estabeleçam particularmente suas regras de justiça; porém, esta diversidade não pode ferir a eqüidade, tomada como universal, revelando uma exigência teleológica que se sobrepõe à diversidade factual. O direito positivo está baseado nas decisões humanas particulares e não são iguais em todos os lugares, o que revela a importância da historicidade da lei e da soberania da comunidade ( $E N$ V, 7, 1135 a 4-7). Disso se poderia concluir um particularismo forte na teoria da justiça de Aristóteles. Entretanto, mesmo considerando apenas a justiça legal, evidencia-se seu caráter normativo, pois a lei determina o que é justo de maneira generalizante, tendo em vista as ações particulares dos indivíduos, isto é, as regras legais (de justiça) servem para estabelecer uma norma para as ações particulares, estabelecendo um mecanismo normativo para a orientação do particular.

Pelo que foi exposto, é razoável concluir que a teoria da justiça aristotélica utiliza um mecanismo substancial para validar (fundamentar) os princípios de justiça da comunidade política, ${ }^{28}$ porém, como até o ordenamento natural é mutável (caso da ambidestria em EN V, 7, 1134 b 33-35), o ordenamento legal (convencional) tem o seu espaço assegurado. Este espaço de ação da justiça legal é o espaço da indeterminação da justiça natural, de forma que as regras de justiça passam a ter um caráter procedimental. Aqui, o direito natural serve como uma idéia orientadora para o direito positivo, não sendo considerado em uma esfera puramente moral. Isso é claramente defendido no momento da distinção entre o

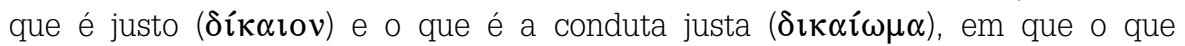
determina o que é justo é ou a natureza ou uma convenção, sendo que o ato justo (conduta justa) só é determinado a partir de sua realização, ${ }^{29}$ tendo como base a voluntariedade da ação, significando que a justiça política, tanto no seu aspecto natural ou legal, serve para o estabelecimento dos princípios públicos de justiça, enquanto a conduta justa dos indivíduos será analisada na esfera da moralidade individual com base na deliberação.

${ }^{28}$ Para Aubenque, a teoria da justiça de Aristóteles possui um caráter naturalista, opondo-se ao procedimentalismo e ao formalismo dos modernos; porém, esse naturalismo não conduziria necessariamente ao relativismo por estar fundamentado no télos humano, que como animal racionallingüístico, tem uma tarefa coletiva a cumprir para alcançar o bem comum, revelando um caráter universalista (AUBENQUE, 1998, p. 43). Essa fundamentação da justiça a partir da natureza (phýsis) humana, entendendo por natureza a atualização de uma potência, nos conduz à definição de homem como animal de linguagem e político, que significa dizer que ele só atualizará sua potencialidade com o exercício racional-lingüístico na convivência pública, na comunidade política e, assim, realizará seu télos.

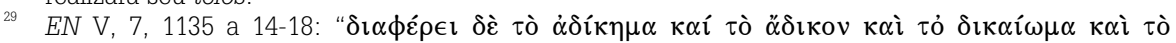

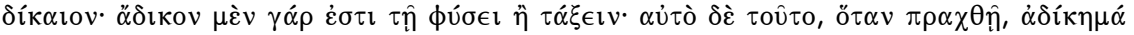

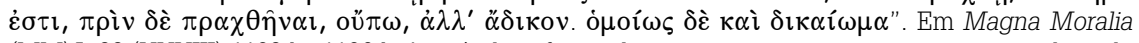
(MM) I, 33 (XXXIII) 1193 b -1196 b Aristóteles afirma claramente que mesmo a justiça natural sendo melhor que a legal, o que é objeto da investigação é a justiça pública e, neste contexto público, o justo é o legal e não o natural. Para comprovar o argumento, estabelece também a distinção entre o justo e o ato justo. 
O que determina que as ações dos indivíduos sejam justas, caracterizando a conduta justa, é a voluntariedade da ação com base na deliberação do sujeito. ${ }^{30}$ Aqui se encontra a esfera da moralidade, pois somente a ação voluntária, com base na vontade do agente, pode ser classificada como uma conduta justa ou injusta no sentido moral. Essa ação voluntária é caracterizada por Aristóteles como uma ação realizada conscientemente, em que é possível o indivíduo identificar todos os elementos implicados (os envolvidos, o instrumento e o resultado da ação), excluindo-se as ações acidentais e realizadas sob coerção, sendo realizada por escolha após a deliberação. ${ }^{31}$ Essa esfera da moralidade implica a deliberação do indivíduo para a realização do ato justo de forma

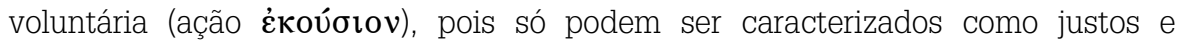
injustos, no sentido moral, aqueles atos que são praticados após a deliberação

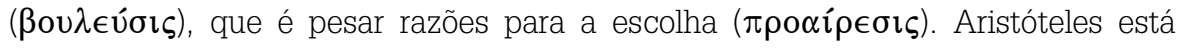
preocupado em perceber que nem todos os atos que são maus podem ser considerados injustos, como uma deficiência moral, como no exemplo dos atos cometidos por ira que não são premeditados com uma intenção criminosa, pois o início da ação não se encontra no agente. Os atos que são considerados moralmente injustos são aqueles em que toda ação é realizada premeditadamente de forma a não respeitar a proporcionalidade e a igualdade, isto é, não respeitando a igualdade, a liberdade e a diferença dos indivíduos. No que se refere a sofrer uma injustiça, isto é, a sofrer uma ação injusta, tal ato é sempre involuntário ( $E N$ $\mathrm{V}, 8,1136$ b 37-38). Isso revela a distinção entre a esfera ética de responsabilidade individual para a ação correta e a esfera da justiça, entendida enquanto moralidade pública, que procura estabelecer uma mediania entre o sofrer uma injustiça e praticar uma injustiça no que diz respeito a igualdade e a distribuição, sendo que a determinação do ato justo é estabelecido pela ação voluntária ou involuntária, sendo este o âmbito da moral privada, ao passo que o âmbito público quer estabelecer um ponto eqüitativo entre (1) sofrer uma injustiça, que é sempre involuntária, e (2) cometer uma injustiça, que pode ser tanto voluntária como involuntária. ${ }^{32}$ Para Aristóteles, essa esfera ética da justiça apresenta uma grande

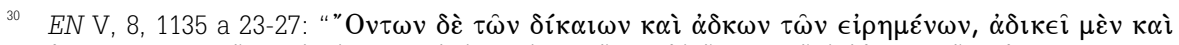

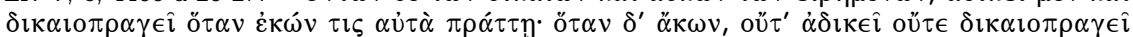

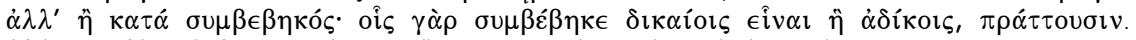

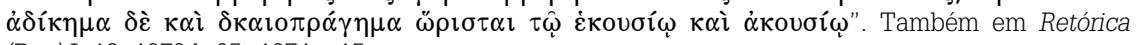
(Ret.) I, 13, 1373 b 25- 1374 a 15.

31 Os atos são realizados com premeditação são praticados após a deliberação, isto é, após o entendimento dos aspectos que estão envolvidos e a escolha de agir dessa ou daquela maneira e os atos que são praticados sem premeditação são realizados sem deliberação. A determinação do que é moral (justo) utilizará como critério último a deliberação voluntária do sujeito (EN V, 8, 1135 b 2022).

${ }^{32}$ A justiça que tem relação com a ação voluntária ou involuntária é a esfera da moralidade, em que a determinação do justo será alcançada pelo indivíduo prudente, que escolhe livremente e delibera pela ação, adequando um universal ao particular. A justiça política ou justiça eqüitativa quer estabelecer uma mediania entre o sofrer uma injustiça e agir injustamente, utilizando, para tanto, um procedimento justo baseado nos princípios de igualdade/liberdade e diferença para estabelecer a eqüidade na comunidade política. 
dificuldade, a saber, não é fácil conhecer aquilo que é justo, pois não é simples saber que ações devem ser praticadas e que distribuições devem ser realizadas para se alcançar o justo. Esse conhecimento ético não se resume em apenas identificar na lei aquilo que deve ser feito, pois a lei só determina o que é justo acidentalmente, e nem identificar na natureza o que é justo, pois isso apenas remeteria a um universal desvinculado da realidade. O que é fundamental nesse raciocínio é que o conhecimento ético da justiça constitui um conhecimento difícil, pois ele não é apenas a identificação de um universal ou de um particular convencionado, mas, sim, é um conhecimento prudente que opera com a razão prática adequando um princípio generalizante ao particular. Esse tipo de formulação não está incluído de maneira absoluta na justiça política, a qual trata das relações públicas dos indivíduos que são livres e iguais e possuem uma vida em comum para a satisfação das necessidades tendo por fim a auto-suficiência. Da mesma forma que o direito natural é uma idéia orientadora para o direito positivo, a responsabilidade ética do indivíduo serve como parâmetro para o estabelecimento de princípios de justiça no sentido político, não sendo determinante para sua realização.

Por fim, em EN, V, 10, Aristóteles investiga a respeito do papel da eqüidade ( $\dot{\varepsilon} \pi \imath \in \mathfrak{\imath} \kappa \in \mathfrak{l} \alpha)$ e sua relação com a justiça ( $\delta \iota \kappa \alpha \iota o \sigma u ́ v \eta)$, isto é, quer saber se elas são idênticas ou se possuem diferenças entre si. ${ }^{33}$ Em primeiro lugar, tem-se uma identificação entre a eqüidade e a justiça, em que a eqüidade significa o mesmo que a justiça (EN V, 10, 1137 b 30-34; MM, II, 2), pois o que a justiça visa é sempre o eqüitativo, sendo que o eqüitativo é o justo no sentido proporcional e aritmético; porém, a justiça (como princípio) possui uma força legal (justiça política) que a eqüidade, por ser uma virtude, não possui. Em segundo lugar, a

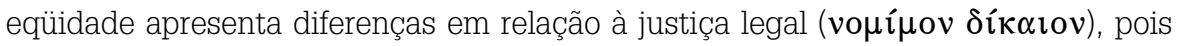
ela é uma espécie de corretor ( $\dot{\varepsilon} \pi \alpha \nu o ́ \rho \theta \omega \mu \alpha)$ da justiça legal, ${ }^{34}$ particularizando a generalidade da lei, de forma a oferecer um juízo eqüitativo nos casos em que a lei

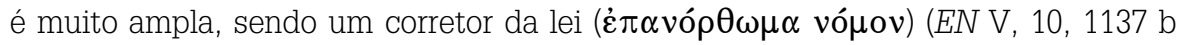
50-52) e, também, um corretor no sentido de aplicação concreta da justiça, em função de a lei ser uma regra geral que não oportuniza concretamente a justiça nos casos particulares (EN V, 10, 1137 b 52-58; MM II, 2). Em terceiro lugar, temse que a eqüidade é uma virtude ética (moral), pois aquele que a possui faz o que

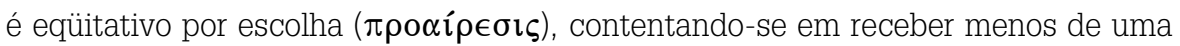
parcela, mesmo tendo a lei a seu favor ( $E N$ V, 10, 1137 b 61-65). Aqui se verifica

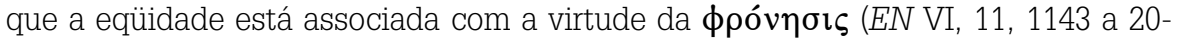
22), pois é a razão prática que determina essa exata correção, possibilitando o encontro da regra correta para a ação particular. A eqüidade não tem a função de

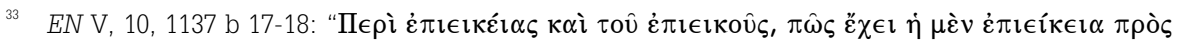

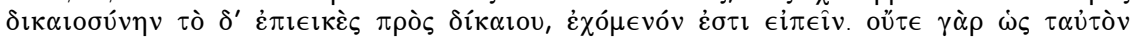

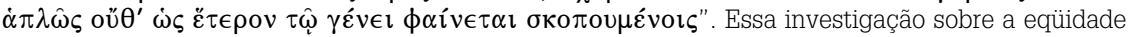
é também realizada na Ret. I, 13, 1374 a 20 - 1374 b 20.

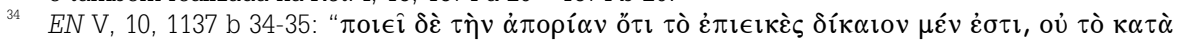

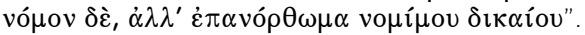


substituir a justiça regular das leis, pois é uma virtude que não possui força coercitiva. Entretanto, apresenta-se como uma espécie de complemento para o ordenamento legal, o que conecta, novamente, a justiça desenvolvida enquanto princípios com a justiça compreendida como virtude.

A teoria da justiça aristotélica tem a finalidade de estabelecer a eqüidade nas relações sociais, políticas e econômicas da comunidade política. Em que pese sua diferenciação, justiça e eqüidade são fundamentais para a constituição do ordenamento político equilibrado, que necessita da justiça entendida como moralidade pública, que apresenta uma norma geral para a garantia da igualdade, da liberdade e da diferença, necessitando, também, da eqüidade, que possui um sentido moral para analisar o caso particular visando garantir a singularidade. A eqüidade opera a partir do modelo eudemonista da ética das virtudes, que necessita da deliberação subjetiva para a determinação do justo (eqüitativo), enquanto a justiça opera com critérios mais objetivos baseados em um princípio matemático da igualdade que necessita ser aprovado na comunidade política. A justiça enquanto virtude ou a virtude da eqüidade estabelecem o âmbito da moralidade das relações públicas na comunidade política. Aqui está o seu limite, pois, por ser subjetiva, não oportuniza regras mais objetivas para assegurar a igualdade e a liberdade dos indivíduos. Por isso, a teoria da justiça irá se construir, também, no âmbito da moralidade pública, a partir do critério universal da igualdade/liberdade e diferença, visando estabelecer a eqüidade nas relações públicas dos indivíduos que são livres e iguais e que têm interesses comuns para a conquista da auto-suficiência.

\section{Considerações finais}

Parece não ser uma solução estranha ao pensamento de Aristóteles a de estabelecer uma complementaridade entre concepções diferentes e, por vezes, até antagônicas, realizando a correção de ambas. No caso de sua teoria da justiça, a complementaridade parece que se estabelece ao considerar a justiça como virtude (justiça universal - vó $\mu \iota \mu$ s), concepção socrático-platônica que engloba a questão da justiça no âmbito da moralidade privada e, também, em considerar a justiça como critério público de correção da pólis (justiça eqüitativa - ı̌oos), integrando uma compreensão teleológica e substancial com uma visão universalista e procedimental. A análise da teoria da justiça de Aristóteles revelou a possibilidade de encontrar em sua ética um modelo complementar entre virtudes e princípios, fazendo uso tanto dos critérios perfeitos oportunizados pelas virtudes quanto das referências públicas dos princípios. Entretanto, essa complementaridade não afirma uma redução dos princípios de justiça à moralidade privada, mas, possibilita identificar a relevância moral no político-jurídico. Por isso, a justiça natural

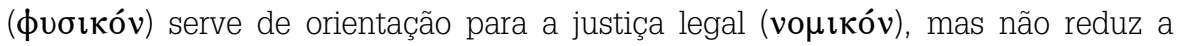
justiça à moral, pois a justiça legal é construída no espaço deixado em aberto pela justiça natural, que é igualmente mutável. Também a responsabilidade individual,

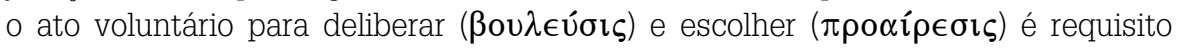


importante para a ação justa, porém, o ato justo não é igual ao ato moral, ao ato

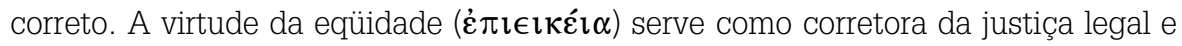
isso implica pensar em um procedimento de equilíbrio reflexivo, em que o sujeito moral deve corrigir a generalidade da lei para determinar o que é correto na ação particular. Por outro lado, essa generalização da lei serve de parâmetro normativo para pautar a deliberação do sujeito.

Isso pode significar que a justiça não é reduzida ao funcionamento da teoria das virtudes em um âmbito privado, tendo uma certa independência principialística para agir; entrementes, é este critério dado pela virtude que possibilita a orientação última da esfera pública. Procurei apontar que a teoria da justiça aristotélica privilegia a esfera pública para estabelecer a eqüidade nas relações sociais e políticas, instituindo princípios de justiça que respeitam a liberdade, a igualdade, a diferença, a reciprocidade e a legalidade, a partir de um modelo procedimental que utiliza uma referência moral para o ordenamento político, sem realizar uma completa redução da esfera da moralidade pública à esfera da moralidade privada. Acredito que além de desejável, foi possível apontar, na filosofia prática aristotélica, uma tentativa de estabelecimento de um modelo ético complementar, em que se encontra a validade das virtudes e dos princípios como critérios morais.

\section{Referências}

ARISTÓTELIS. Ethica Nicomachea. Ed. I. Bywater. Oxford: Oxford University Press, 1894 (Reimp.1962).

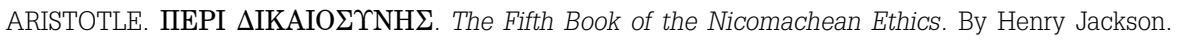
New York: Arno Press, 1973. (Reimp. 2003) Eudemian Ethics. Ed. Jefrey Hederson. Cambridge, Mass: Harvard University Press, 1926 Magna Moralia. Ed. G. P. Goold. Cambridge, Mass: H. U. P., 1935 (Reimp. 1997). Metaphysics. Ed. G. P. Goold. Cambridge, Mass: H. U. P., 1933 (Reimp. 1996). Politics. Ed. Jefrey Hederson. Cambridge, Mass: H. U. P., 1932 (Reimp. 2005). Rhetoric. Ed. Jefrey Hederson. Cambridge, Mass: H. U. P., 1926 (Reimp. 2000).

AUBENQUE, Pierre. "Aristote était-il communitariste?". In: GÓMEZ, A.; CASTRO, R. En Torno a Aristóteles: homenaje al profesor Pierre Aubenque. Santiago de Compostela: Universidade, Servicio de Publicacións e Intercambio Científico, 1998, pp. 31-43.

. La Prudence chez Aristote. 2. ed. Paris: PUF, 1976

(Direction). Aristote Politique: Etudes sur la Politique d'Aristote. Paris: PUF, 1993.

BARNES, Jonathan. The Cambridge Companion to Aristotle. Cambridge: Cambridge University Press, 1996.

BODÉÜS, Richard. "La justice, état de choses et état d'âme". In: DESTRÉE, Pierre (Coord.). Aristote: Bonheur et Vertus. Paris: PUF, 2003, pp. 133-146.

BROADIE, Sarah. In : Aristotle. Nicomachean Ethics. Trasl. C. Rowe. Philosophical introduction and commentary. Oxford: Oxford University Press, 2002, pp. 09-91.

GUARIGLIA, Osvaldo. Ética y Política según Aristóteles II: el bien, las virtudes y la polis. Buenos Aires: Centro Editor de América Latina, 1992.

HÖFFE, Otfried. "Aristóteles". In: RENAULT, Alain. Histónia da Filosofia Politica 1: a liberdade dos antigos. Trad. Jean Kahn. Lisboa: Instituto Piaget, 2001, pp.111-178.

IRWIN, T. H. Aristotle's First Principles. Oxford: Clarendon Press, 1995. 
"A ética como uma ciência inexata: as ambições de Aristóteles para uma teoria moral". Trad. Sílvia Altmann. Analytica, Rio de Janeiro, 1/3 (1996): 13-73.

KRAUT, Richard. Aristotle on the Human Good. Princeton: Princeton University Press, 1991.

(Ed.). Aristotle's Nicomachean Ethics. Oxford: Blackwell Publishing, 2006.

. Introduction. Aristotle's Nicomachean Ethics. Oxford: Blackwell Publishing, 2006, p. 1-11.

MILLER, Fred. D. Nature, Justice, and Rights in Aristotle's Politics. Oxford: Oxford University Press, 2001.

MONTOYA, José. "Aristóteles: justicia y racionalidad practica". In: GÓMEZ, A.; CASTRO, R. En Torno a Aristóteles. Santiago de Compostela: Universidad, Servicio de Publicación e Intercambio Científico, 1998, pp. 257-267.

NATALI, Carlo. The Wisdom of Aristotle. Transl. Gerald Parks. Albany: SUNY Press, 2001.

. "Por que Aristóteles escreveu o Livro III da EN? Trad. Inara Zanuzi. Analytica, Rio de Janeiro, 8/2 (2004): 47-75.

NUSSBAUM, Martha. The Fragility of Goodness: luck and ethics in greek tragedy and philosophy. Cambridge: Cambridge University Press, 1986.

RORTY, Amélie (Org.). Essays on Aristotle's Ethics. Los Angeles: University of California Press, 1980.

ROSS, David. Aristotle: with a new introduction by John Ackrill. London: Routledge, 1996.

URMSON, J.O. "Aristotle's doctrine of the mean". In: RORTY, Amélie (Org.). Essays on Aristotle's Ethics. Los Angeles: University of California Press, 1980, pp. 157-170.

WILLIAMS, Bernard. "Justice as a Virtue". In: RORTY, Amélie (Org.). Essays on Aristotle's Ethics. Los Angeles: University of California Press, 1980, pp. 189-199.

YOUNG, Charles. "Aristotle's Justice". In KRAUT, R. (Ed.). The Blackwell Guide to Aristotle's Nicomachean Ethics. Oxford: Blackwell Publishing, 2006.

ZINGANO, Marco. "Eudaimonía e bem supremo em Aristóteles". Analytica, Rio de Janeiro, 1/2 (1994): 11-40.

$75-100$

"Particularismo e universalismo na ética aristotélica". Analytica, Rio de Janeiro, 1/3 (1996):

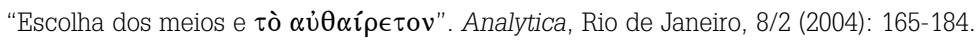

